\title{
地球規模課題対応国際科学技術協カプログラム (SATREPS)
}

\section{研究課題別中間評価報告書}

\section{1. 研究課題名}

メキシコ沿岸部の巨大地震・津波災害の軽減に向けた総合的研究

(2016 年 5 月〜2021 年 5 月)

\section{2. 研究代表者}

2. 1. 日本側研究代表者: 伊藤 喜宏（京都大学 防災研究所 准教授）

2. 2. 相手国側研究代表者 : Victor Cruz-Atienza

（メキシコ国立自治大学 地球物理学研究所 教授）

\section{3. 研究概要}

本研究課題は、メキシコ太平洋沿岸部のココスプレート沈み込み帯にあるゲレロギャップ（ゲ レロ州沖合の巨大地震空白域）に、はじめて海底に圧力計や地震計を設置しスロースリップ（摇 れを伴わない遅い速度で発生するプレートの滑り現象）に伴う現象のデータを取得する。陸上の 衛星測位システム (GNSS) の観測点や地震観測点から得られたデータと合わせて解析し、プレー 卜構造のモデル化や地震・津波のシミュレーションを行う。さらにゲレロ州沿岸部で将来発生し うる巨大地震や津波の災害シナリオを作成し、地震や津波のリスクを評価し、ハザードマップを 構築する。また、現地の社会 · 文化的特性に配慮した減災教育プログラムを開発する。

スロースリップや巨大地震のメカニズムについて、日本・メキシコ両国の類似性 ·相違性を理 解することは、わが国の南海トラフで発生すると見込まれる巨大地震 · 津波の本質的理解につな がり、将来の大震災から生命および財産を守る社会の持続的発展の実現に資する。

本研究課題は以下の $6 \supset$ つ研究題目で構成される。

$A-1$ : 海底観測（海底地震 ・ 圧力観測、海底津波堆積物調査）

$\mathrm{A}-2$ : 陸上観測（陸上地震 ・測地観測網の強化）

B-1 : 地震モデリング（地震サイクル・強震動・スロースリップ・温度構造モデル）

B-2 : 津波モデリング（津波波源・遡上浸水モデル、津波モニタリングシステム）

C-1：脆弱性・リスク評価（構造物・地域経済に関する評価、リスクマップの開発・運用）

C-2 : 教育プログラム開発（減災教育プログラム等の開発と普及、津波被害記録調査）

\section{4. 評価結果}

総合評価 : $\mathrm{A}+$

(所期の計画をやや上回る取り組みが行われ、大きな成果が期待できる) 
各研究題目が順調に進捗し今後の研究成果が期待される。観測に関する研究活動において、ス ロースリップイベント (以下、SSE) と思われる現象を捉えており、今後データの解析が進めば SSE に関する理解が進展することが期待できる。また、研究者のレベルが高く研究代表者のリーダー シップもあり、相手国側研究代表機関が独自に政府研究予算を獲得してウェーブグライダー（自 立航行船舶）を導入したことなどもあって、海底観測データが効率的に取得できる研究環境が整 うなど、全般的に高いレベルで研究が進展している。SSE の解明に向けた分析等も今後活発に行 われることが大いに期待される。

沈み込む海洋プレートに関する地震モデリング研究にて、熱的構造の理解などが進展し、当初 の計画以上に進捗している。また、津波モデリングでは確率を考慮した津波の解析が行われ、そ の成果が得られていることは研究活動が進展している証しであるといえる。また、社会実装に向 けた取り組みとして、津波災害軽減のための防災教育面での活動も活発に行われ、これまで世界 津波の日（11月 5 日）にちなんだ啓発イベントが実施されたほか、多数の避難訓練などが実施さ れてきた。

また、2017 年 9 月に発生したチアパス州沖地震についてのプレート破壊に関する解析が行わ れ、メキシコシティ近郊で同月に発生した大地震においても、被害状況の確認やそれを受けたプ ロジェクトの活動方針が両国研究者の議論で検討された。両国の研究者代表者のリーダーシップ が活かされ、当地の地震災害に対応した適切なプロジェクト運営がなされている。

科学的成果の面では、数篇のオリジナル論文が発表されているものの、インパクトの高い論文 は現時点では多くはない。脆弱性・リスク評価においては、観測研究やモデリングで得られた知 見が統合化され社会実装への道筋をつける重要な役割を担うが、対象とする市街地の特徴を詳細 に捉え予測精度を上げるエ夫が求められる。既成のモデル解析手法の利用だけでなく、得られた 知見に基づき新規性・進歩性を有する改良がなされることが期待される。

以上を総括するに全体としては所期の計画をやや上回る取組と評価できる。

\section{4ー1. 国際共同研究の進捗状況について}

観測研究についてはほぼ計画通りに進捗していることに加え、沈み込む海洋プレートに関する シミュレーション研究に関しては熱的構造などを含めて、当初の計画以上に進捗している。また、 防災教育に関しては、初年度から現地での活動を続け、現地参加者も想定以上である。今後観測 データの解析が進み、新たな津波発生モデルなどに併せて、避難計画などのチューニングが進め ば、想定以上の成果が期待できる。

相手国側研究代表機関が研究資金を獲得し、ウェーブグライダーを導入したことは、今後海底 観測点のデータ回収を行う上で大きく貢献すると考えられ、設置した海底水位計を津波監視装置 として活用できる可能性を拓いたと言える。

政府方針によって高額なケーブル式の海底観測装置が設置されている我が国に比べれば、本プ ロジェクトにて相手国に導入された観測装置のレベルは決して高くはないが、通常の大学や研究 機関で研究を推進する上では、十分な機材であると言える。 
これまで海底観測を行っていなかった相手国が持続的に海底観測を継続できるようになれば、 重要な成果が得られることが期待できる。本研究で目指しているSSE と大地震との関連に関する 理解が進めば、わが国における南海トラフでの大地震の理解にも大きな貢献が期待できる。ただ し、SSE に焦点が当てられているものの、空白域及びその周辺域における通常の地震活動の状況 を把握することも重要である。精度の高い震源決定を含めて今後も抜かりなく調査を実施いただ きたい。

\section{4-2. 国際共同研究の実施体制について}

各研究チームは大きな問題なく計画をこなしており、研究代表者が全体の進捗を正確に把握し つつ適切に統括していると評価できる。担当する観測研究だけでなく、防災教育の活動において も日常的に関与し、他の研究グループや相当なポテンシャルを有する相手国研究者とのコミュニ ケーションも良好である。このように研究代表者のリーダーシップはいかんなく発揮されている。

購入機器や貸与機器など、研究費は有効に活用されている。観測機器の海底への設置や、それ らからのデータの回収には相手国研究代表機関の海洋調査船の活用が不可欠であるが、相手国研 究者の努力によって、今のところ順調に実施できている。それに加えて、相手国研究代表機関が 独自に国の研究資金を獲得し観測機材の充実が図られ、期待以上の研究活動がなされている。

\section{4ー3. 科学技術の発展と今後の研究について}

我が国が抱える南海トラフにおける地震 ·津波の問題と密接に関係する研究テーマであり、本 研究で展開しているソフト面での防災対策も含めて、わが国の科学技術に貢献できるもので、そ の成果は期待できる。

観測研究においては、SSE と地震発生の機構解析を目的としてゲレロ空白域へ観測機器を設置 したことなど順調に推移しており、進め方に問題はない。SSE の観測とデータ解析を通して研究 成果が得られてくれば、より高いインパクトが得られるものと考えられる。また、SSE の観測研 究に偏るだけではなく、空白域及びその周辺の地震発生場のより詳しい性質を解明することも重 要である。この意味では、モデリングに温度場の推定を取り入れていることは適切である。地殼 熱流量等による数值計算拘束条件についてその妥当性を明確にし、温度場推定の信頼性を今後高 めていただきたい。

津波モデリングの研究は、日本側研究者の主導で進められているが、陸上部分の津波遡上解析 は津波被害を低減するために重要なものである。研究対象としている地域は狭い領域ではあるが、 建物や街路の形状等、地域の特殊性を考慮し様々な条件を加えて、精度良く新規性のある解析結 果を創出していただきたい。

防災教育に関する活動では、日本側若手研究者が長期間派遣され、現地の活動を主体的に推進 しており、コミュニケーションも良好で相手国関係者の信頼も得ている。現在は学校の枠組みで 子どもや学生を対象としたアプローチがなされている。加えて地域コミュニティーや大人に対す る教育も重要であり、大人に対するアプローチはこれまでのものと異なることも想定して開発を 
進める必要があるかもしれない。

\section{4-4. 持続的研究活動等への貢献の見込みについて}

相手国研究者のレベルは非常に高く、対等な国際共同研究が行われていると言える。本プロジ エクトにて海底観測と陸域観測を同時に行うことの重要性が理解された上で相手国の公的研究資 金を獲得してウェーブグライダーを独自に導入するなど、研究の継続性を強く意識した活動が促 進されており、研究の持続的発展は大いに期待できる。

主要メンバーに若手が多く、地震科学を中心に今後も活発な人的交流が見込まれ、国際共同研 究の結果として研究人材ネットワークの深化が大いに期待できる。相手国は中南米に位置してい るため、太平洋を隔てたわが国よりは研究者の視線は主に北米を向いているが、本研究によって 我が国に留学する学生も現れ、人材交流も今後期待できる。

津波被害軽減に向けた取組を含む現地住民への教育・啓発活動は極めて重要であり、コンテン ツをエ夫するだけでなく組織的な活動が重要であると考える。現時点では、市や関係機関との調 整が順調であり成果が持続的に発展する見込みがある。

今回開発される津波の遡上モデル、避難経路モデルや防災教育素材、今後行われる経済影響評 価が相手国の政策等に反映されるためには、それらの研究成果がいかに行政にとって魅力的なも のであるかが重要であり、上記教育 · 啓発活動も含めて、当地の関係者のフォードバックを常に 得ながら改良を進めていただきたい。

\section{5. 今後の課題 - 今後の研究者に対する要望事項}

本プロジェクトにおける海域観測活動では、相手国研究代表機関の海洋調査船による航海が必 須である。このような活動の維持においては、今後も相手国での研究リソースの確保が重要であ る。そのためには観測により着実に研究成果が得られていることを両国研究者が強く自覚するこ とが最大のモチベーションになりうる。回収したデータの解析を急ぎ、陸上観測装置からのデー タや、モデリングの成果とのすり合わせにより、合理的なモデルへのブラッシュアップを急ぎ、 研究成果を見える形に仕上げる努力を継続していただきたい。

プレート沈み込み帯における SSE の現象理解ならびに、プレート間の巨大地震と SSE の関係を 明確にすることが期待されている。本プロジェクトでは、SSE を観測することが重要なポイント であるが、限られた国際共同研究期間においてそれらを観測できうる回数はきわめて限られるは ずである。そのため、SATREPS 終了後も持続可能な国際共同研究体制の確立が非常に重要となる。 相手国側研究代表機関の自助努力で観測のためウェーブグライダーが導入されたことを契機に長 期的な共同研究体制を抜かりなく構築していただきたい。

以上 
成果目標シート

\begin{tabular}{|l|l|}
\hline 研究課題名 & $\begin{array}{l}\text { メキシコ沿岸部の巨大地震·津波災害の軽減に向け } \\
\text { た総合的研究 }\end{array}$ \\
\hline $\begin{array}{l}\text { 研究代表者名 } \\
\text { (所属機関) }\end{array}$ & $\begin{array}{l}\text { 伊藤 喜宏 } \\
\text { (京都大学防災研究所) }\end{array}$ \\
\hline 研究期間 & H27採択(平成27年6月1日〜平成33年3月31日) \\
\hline $\begin{array}{l}\text { 相手国名/主 } \\
\text { 要相手国研究 } \\
\text { 機関 }\end{array}$ & $\begin{array}{l}\text { メキシコ合衆国/メキシコ自治大学、国立防災セン } \\
\text { ター }\end{array}$ \\
\hline
\end{tabular}

\begin{tabular}{|c|c|}
\hline \multicolumn{2}{|r|}{ 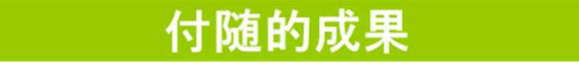 } \\
\hline $\begin{array}{l}\text { 日本政府 } \\
\text { 社会、産業 } \\
\text { への貢献 }\end{array}$ & $\begin{array}{l}\text { ·南海ラフ沿いの巨大地震·津波災害 } \\
\text { 軽減の取り組みへの活用 } \\
\text { 日本国内におけける地震·津波減災教育 } \\
\text { プログラの改善 }\end{array}$ \\
\hline $\begin{array}{l}\text { 科学技術の } \\
\text { 発展 }\end{array}$ & $\begin{array}{l}\text { ·他っく地震と巨大地震の相互作用の } \\
\text { ·解明 } \\
\text { 発率論的津波予測手法の確立および }\end{array}$ \\
\hline $\begin{array}{l}\text { 知財の獾得 } \\
\text { 国際標隼化 } \\
\text { の推進、生 } \\
\text { 物盗源への } \\
\text { アクセス等 }\end{array}$ & 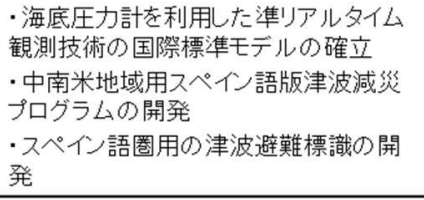 \\
\hline $\begin{array}{l}\text { 世界で活躍 } \\
\text { できる日本 } \\
\text { 凡人材の育 } \\
\text { 成 }\end{array}$ & $\begin{array}{l}\text { ·国際的に活躍可能な日本側の若手研 } \\
\text { 究者の育成(国際会議への指導力、レ、レ } \\
\text { ビーー付雑読への論文掦載など) }\end{array}$ \\
\hline $\begin{array}{l}\text { 技術及び人 } \\
\text { 的ネット } \\
\text { ワークの構 } \\
\text { 築 }\end{array}$ & $\begin{array}{l}\text { •メキシコ海底地震·測地学分野の構築 } \\
\text { ·災害軽減フロログラム実施コミュニティ } \\
\text { の構筑 }\end{array}$ \\
\hline $\begin{array}{l}\text { 成果物(提 } \\
\text { 言書、論文、 } \\
\text { アログラム. } \\
\text { マニュアルル } \\
\text { データなど) }\end{array}$ & 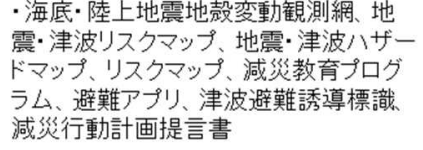 \\
\hline
\end{tabular}

\section{上位目標}

中南米・かリブ地域に津波減災教育プログラムが普及・活用される。

ゆっくり地震と巨大地震発生プロセスが本質的に理解される。

メキシコ国内においてリアルタイム津波システムが構筑される。

\section{$\longrightarrow$}

メキシコ国内の政策に地震·津波ハザードマップが採用される。 仨シコ国内でで津波減災教育プログラムが活用される。

\section{プロジェクト目標}

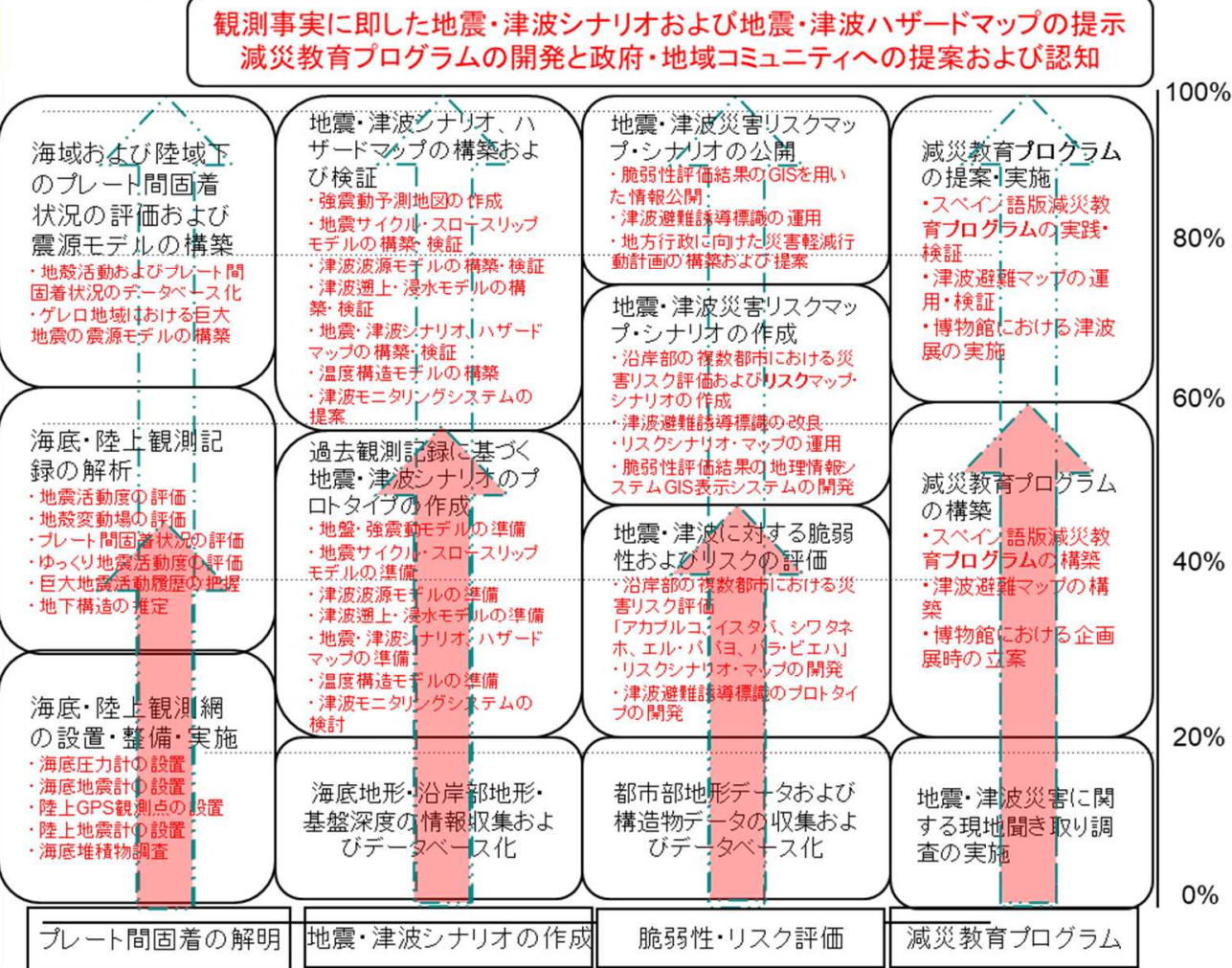

図 1 成果目標シートと達成状況（2019 年 2 月時点） 